\title{
Social Indicators and the Study of Inequality
}

M arcia K. M eyers and I rwin G arfinke

As we near the close of the twentieth century, communist regimes have collapsed and the productivity of capital ism is universally acclaimed. In all the W estern democracies, welfare state institutions are being challenged. The challenge is, arguably, the most fundamental in the U nited States. Proposals to privatize public education and oldage insurance are now mainstream. The 1996 Personal Responsibility and Work Opportunities Reconciliation Act represents the most recent, and is likely to be the most influential, change in public policy for the poor. By eliminating the historical entitlement to welfare, and devolving responsibility for welfare programs to the states, the Personal Responsibility Act dramatically changes the nature, level, and locus of government responsibility for the poor. Other policy changes- such as the creation of the Children's H ealth Insurance Program and Child Care and Development Block Grant- have expanded resources and state-level discretion for the provision of support.

Supporters of the retrenchment and devolution of federal programs predict that these changes will improve

$M$ arcia $K$. M eyers is the assodiate di rector and I rwin $G$ arfinkel the chair of the $\mathrm{N}$ en Y ork City Social Indicators Survey $\mathrm{C}$ enter of Columbia U niversity. The vi ews expressed are those of the authors and do not necessarily reflect the position of the $F$ ederal Reserve B ank of $N$ ew $Y$ ork or the $F$ ederal R eserve System. the fortunes of the most disadvantaged Americans and help close the growing gap between the rich and the poor. Critics predict that these same changes will harm the poor and increase inequality. The disagreement stems, in part, from different expectations about the intermediate impact of devolution on government, community, and family systems. Some observers argue that government has displaced support from the family, community, and voluntary sectors; they expect government retrenchment to enhance the capacity and contribution from these nongovernmental systems. Others argue that government has a unique capacity to support disadvantaged populations and to promote greater equality in economic and social outcomes; they fear that government retrenchment will create a level of need that will overwhelm private systems and force individuals to turn to unreliable and unacceptable al ternatives.

Efforts to confirm or disprove predictions such as these are creating new opportunities, al ong with new challenges, for scholars who are interested in questions about economic security and equality. New opportunities are arising with the "natural experiments" that are created as state and local governments revise, redesign, and reduce a variety of income assistance and social service programs. $\mathrm{N}$ ew challenges are arising as analysts attempt to track the rapidly changing policy landscape and collect data with which to eval uate the impact of the changes. 
The N ew York City Social Indicators Survey (SIS) project represents one effort to track the consequences of policy reform and devolution for inequality and well-being in the largest and most diverse city in the U nited States. The project uses a telephone survey to collect data from a repeated cross-sectional sample of the entire city population. The survey will collect detailed information on families' economic resources, assets, external support, and health and well-being. By analyzing these data by population and over time, we hope to address questions that are at the core of current debates about inequality in the U nited States: H ow great is inequal ity? Does income inequal ity exaggerate, or reflect, inequality in material and social living conditions, health, and well-being? Is inequality on these dimensions growing or shrinking? And what effect have devolution and social policy "reform" had on the magnitude of income and other forms of inequality?

In the following sections, we present first-year findings from the project. We begin with an overview of the issues that motivated the project and a brief summary of our measures and data-collection methods. The next sections use data collected in 1997 to tell the story of income and outcome inequality in the city-first, in terms of comparisons between the well-being of $\mathrm{N}$ ew Yorkers and the rest of the U.S. population; second, in terms of the well-being of poor and economically secure residents of the city. We conclude by describing future research plans for the Social Indicators project.

\section{BACK GROUND}

The N ew York City Social Indicators Survey demonstrates the use of social indicators - repeated, population-based measures of economic, social, and health outcomes- to answer questions about inequality and well-being. Social indicators were widely embraced in the 1960s, fueled by the recognition that social and heal th policymakers needed better tools for monitoring and reporting on social and health conditions (Carley 1981). Government agencies and academic institutions took advantage of a vastly improved capacity for data collection and storage to amass information on a variety of social and economic processes and outcomes. A nalysts hoped to use these data to document trends and progress toward increasing well-being and reducing inequality in income, health, and other outcomes. These efforts largely disappointed their sponsors' highest hopes. Social indicators based on aggregate data - such as poverty rates, infant mortality, or child abuse and crime victimization reports- proved to be both insufficiently sensitive, as measures of policy impact, and overly aggregated, as indicators of the well-being of populations at the subnational level (Andrews 1989; Bulmer 1989; J ohnston 1989).

A number of factors have combined to fuel a resurgence of interest in the use of social indicators to track well-being and inequality. Dramatic changes in welfare, health, and social policies are raising questions about whether these reforms will reduce or exacerbate the trend toward greater inequality of income and of outcomes across groups. Meanwhile, the devolution of social and health policies downward, to lower levels of government, and outward, to new government and private entities, has increased the need for reliable measurement of outcomes at the subnational level.

Even as demand for more and better data on income and other outcomes has grown, however, traditional measures and approaches have come under growing criticism. Existing outcome data- available from public administrative records and household surveys- are limited in terms of what is measured, how well it is measured, the extent to which various measures can be aggregated at the individual and household level, and the possibilities for desegregating these anal yses to policy-rel evant geographic areas.

\section{MEASUREMENT AND DATA ISSUES}

Disagreements begin with the question of what to measure. The most widely used indicator of economic well-being and inequality is household income relative to need, measured in terms of the federal poverty threshold. As a measure of income, the official poverty measure, based on current before-tax cash income, is criticized for both over- and underestimating family resources (Citro and Michael 1995). The poverty measure overestimates resources because it fails to adjust for nonelective expenditures- such as taxes, medical costs, and work expenses- that reduce disposable income. At the same time, by excluding in-kind transfers 
such as Food Stamps or housing assistance, the poverty measure underestimates resources that directly improve economic living conditions. The threshold used in the official definition of poverty has also been criticized. Based on a formula established in the 1950s, the threshold is variously criticized for failing to reflect changes in consumption patterns, differences in the rate of inflation for essential expenditures such as housing, and geographic differences in the cost of living (Ruggles 1990; Citro and M ichael 1995). Calculations of both income and the threshold are al so highly sensitive to measures of prices, and some analysts argue that current measures overstate inflation and the extent and growth of poverty and inequal ity since the 1960s (see M ayer and J encks [1995] and Mayer [1997]).

Even if these measurement problems can be solved, many analysts argue that income poverty will still be a poor indicator for tracking the underlying dimensions of economic security and inequality. U sing data from a Chicago survey, Mayer and Jencks (1988), for example, find that a family's official income-to-needs ratio (poverty) explained only 24 percent of variance in the amount of material hardship they experienced on dimensions as basic as hunger, housing adequacy, and medical care. The poverty measure may be an especially flawed indicator of the effectiveness of government efforts to improve economic well-being and reduce inequality. Since the mid-1960s, the major growth in government anti-poverty spending has been for in-kind benefits- through Food Stamps, Medicaid, and housing programs- and for other social service and human capital programs. It is argued by many that, while these programs have made important contributions to the well-being of poor families and may have hel ped close the gap in material security between the poor and the nonpoor, their success has been underestimated because the income poverty is not sensitive to changes in material well-being (for example, see Mayer and J encks [1988] and J orgenson [1998]).

In light of these problems, some scholars have recommended replacing income measures with measures of household expenditure or consumption. H ousehold-level surveys typically find that reported consumption is higher than reported income, and analysts using consumption or expenditure data typically find lower rates of poverty and inequality across households-suggesting that noncash resources may in fact help close some of the gap in cash income between poor and nonpoor households (Cutler and K atz 1992; Slesnick 1993). Consumption measures also capture differences across families who, while they have similar incomes, have quite different consumption needs. Consumption studies comparing the welfare and working poor, for example, reveal that the latter are often worse off (at the same income level) because they have higher nonelective expenses such as transportation, child care, and private medical insurance (Passero 1996; Edin and Lein 1997).

Even more direct indicators of economic well-being are provided by various measures of material conditions. Using eight national surveys, Federman et al. (1996), for example, demonstrate the worst material well-being of poor- relative to nonpoor-children by comparing the groups on dimensions ranging from housing quality to crime victimization, disabilities, hunger, and the presence of books and computers in the home. W hile direct measures such as these cannot resolve the normative issue of how much material inequality or distress is "too much," they can begin to give concrete meaning to the magnitude of the difference between groups and trends over time. Mayer and Jencks (1995) and Mayer (1997), for example, have argued that while differences in material circumstances of poor and nonpoor children remain large, inequality in some measures of material well-being has actually declined in magnitude over time. U sing multiple data sources, they find that between 1969 and 1989, while adjusted incomes declined for the poorest families with children, some measures of concrete well-being-such as housing crowding, housing quality, and access to health care-actually improved. Other measures- such as home ownership, access to a car, and neighborhood safety-declined during the same period.

A final measurement issue concerns the use of outcomes other than economic well-being to estimate the gap between advantaged and disadvantaged individuals. Economic resources and material deprivation are important indicators of well-being and inequality in their own right. 
They are useful predictors of other outcomes as well, because poor individuals, particularly children, have far worse prospects than nonpoor individuals on a range of outcomes, from physical health to educational attainment and socioemotional functioning (Duncan and Brooks-Gunn 1997). Even the best measures of economic well-being are imperfect proxies for these outcomes, however. To track well-being and inequality on health, developmental, social, and other outcomes, it is critical to measure these outcomes directly. We would ideally like across-group and over-time data not only on economic and material circumstances, but also on outcomes such as health, disabilities, educational success, socioemotional adjustment, mental health, and family functioning.

These outcomes are arguably the most important indicators for evaluating well-being and inequality. They may also be the best measures of the impact of public programs, from health insurance to preschool, that are designed to improve the life chances of "at-risk" individuals. They are also the most difficult and expensive indicators to measure and track. As a result, existing individual-level outcome indicators have a number of important limitations.

One of the most severe limitations is that of the data. By far the largest source of data are the administrative records of government programs. These records provide a weal th of information that has been used in recent years to describe the characteristics and circumstances of individuals in public welfare, mental health, child welfare, and other public systems. Although vast, these administrative data are typically quite limited, both by the sample observed (including only individuals who receive government services) and by the type of information collected (designed for program management rather than for tracking individual outcomes). One consequence can be compromises in data quality-data that are either insensitive measures (not reflecting the construct they are intended to measure) or biased by missing data or nonrepresentative samples (Brown and Corbett 1997). Poor data quality has created substantial problems, to use some recent examples, when receipt of an intervention has been substituted for the underlying condition (such as using child-abuse reports as a proxy for child maltreatment); when trends in the data have unclear or ambiguous meaning (for example, recent declines in Food Stamp and M edicaid caseloads); or when data have been available only for a nonrandom subset of the population of interest (for instance, in the use of state employment tax records to measure employment among welfare exiters).

H ousehold-level surveys are the primary alterna tive to administrative data, and a number of population surveys conducted at the national level collect data on individual outcomes ranging from economic security (such as the Current Population Survey) to material well-being (such as the American Housing Survey and the Survey of Income and Program Participation), neighborhood quality (such as the $\mathrm{N}$ ational Crime Victimization Survey), child adjustment and family functioning (such as the Panel Study of Income Dynamics and $\mathrm{N}$ ational Longitudinal Survey of Youth), and health (such as the $\mathrm{N}$ ational Maternal and Infant $\mathrm{H}$ ealth Survey).

$\mathrm{N}$ ational surveys are a rich source of information about how individuals and households are faring. But singlepurpose surveys remain severely limited for the purpose of tracking multipl e outcomes simultaneously at the individual level. For example, in order to answer the question "W hat does it mean to be poor in America?" Federman et al. (1996) drew upon eight different national surveys. Although use ful, this analysis is still limited because, as the authors point out, surveys that address only one or a few aspects of well-being cannot be used to understand either the correlations across various dimensions of well-being or the accumulation of risk factors at the individual level. This is a particularly severe limitation as studies of inequality move beyond simple income comparisons. To understand what it means to be poor, for example, or how the poor are faring relative to the nonpoor, it is important to understand whether a single indicator of hardship (such as hunger or housing adequacy) represents a household-level choice about the allocation of limited resources, or whether it is one aspect of an accumulation of hardship across multiple dimensions. With a few notable exceptions, population surveys do not provide this range of measures.

The use of national surveys to study inequality and well-being is often further limited by sample size. Large 
population samples, or specialized subsamples, are needed to compare well-being across groups, and samples of some of the most vulnerable groups- such as families with young children, or low-income workers, or insecurely housed individuals - are often too small for this purpose. Opportunities to link outcomes to policy variation are al so limited, because most national data sets do not have sufficiently large or representative samples for the geographic areas in which policy is now being formulatedthe state, county, and even local levels.

\section{THE NEW YORK CITY SOCIAL INDICATORS SURVEY}

What is needed for the study of policy reform, wellbeing, and inequality - and what the New York City Social Indicators Survey is designed to provide- is microlevel outcome data that measure a range of critical outcomes, over time, across the entire population, and within a single policy jurisdiction. The SIS will be administered every two years, using a repeated cross-sectional sampling design. The SIS measures family and individual wellbeing on a wide range of economic and noneconomic dimensions.

We begin with individual and family assets- the human, financial, and social resources that individuals accumulate starting in childhood. They are a critical component of well-being because they constitute not only the weal th of the present but al so "capital" for the future. The SIS measures include human assets (health and disability, educational achievement), financial assets (net worth, debt, home ownership, equity), and social assets (access to capital in an emergency, reliance on neighbors, neighborhood support for children).

Because the well-being of children is a particularly important indicator of social health and welfare, the SIS includes a wide array of child outcome indicators. These are supplemented by measures of parenting practices and family routines that are predictive of child outcomes. Specific measures include child outcomes (child heal th and disability, child socioemotional development, child school progress, adolescent risk behaviors) and parenting practices and organization of family routines (supervision of children, familiarity with children's friends, organization of family meals, reading to children).

Human assets and child outcomes provide good indicators of well-being in the present and children's development of human capital for the future. But $\mathrm{N}$ ew Yorkers live in the present. SIS indicators of family living conditions describe the immediatelife circumstances of families and their members. These measures cover both economic conditions (income, difficulty paying utility bills, income-related hunger) and social conditions (housing quality and crowding, crime victimization, neighborhood quality and safety).

Individuals and their families are never entirely self-sufficient. All rely on some forms of external support to assure their well-being, and the availability and quality of these supports are important factors in security and well-being. The source of support-from government, family, community, or the workplace — has other implications for both the adequacy of support and for families' patterns of reliance. To capture these dimensions, the SIS includes additional measures of institutional support (health insurance coverage, qual ity and safety of children's school, use of formal child care) and financial and concrete assistance with child care, educational, medical, housing and food needs from government, family, community programs, and government.

The SIS will be used to collect these measures from a random sample of all $\mathrm{N}$ ew Y ork City households on a biannual basis. Each data set will be a fully representative cross-section of the city's population; over time, samples may be combined to increase the sample of small subpopulations. The data will be used in a variety of ways to describe, track, and analyze well-being and inequality in the city over the coming years.

\section{METHODOLOGICAL ISSUES}

In 1997, the first round of SIS data was collected from a random sample of 2,224 $\mathrm{N}$ ew York City households, using random digit dialing techniques. The sample was designed to be representative of all families in the city. We have used statistical methods to correct the final sample for potential sampling biases. We have corrected for the underrepresentation of households that do not have 
regular phone service by giving extra weight to those who have intermittent service. Other biases, including disproportionate participation by more highly educated respondents, have been corrected by post-stratification weighting using U.S. Census Bureau data. Some limitations in the representativeness of the sample could not be overcome. M ost notable is the exclusion of individuals who could not be interviewed in English or Spanish. Of all households within the random sampling frames who were determined to be el igible for the survey, nearly half (48 to 49 percent) refused to participate. Although this may cause some unmeasured biases in the final sample, once the data are correctly weighted, the sample very cl osely approximates Census Bureau data for the city on major demographic and economic characteristics.

Some specific characteristics of the $\mathrm{N}$ ew York City Social Indicators Survey influence the comparability of its data to other data sources. First, we consider respondents to be partnered whether or not they are legally married to their domestic partners. Estimates from the survey may therefore show higher rates of two-adult and twoparent families than estimates based on other definitions and data sources. Second, we count all individuals in our survey as part of a family. Individuals without partners or resident children are treated as a "family of one," even if they are sharing a residence with other non-nuclear family members (such as adult children) or nonrelated adults (such as roommates). This definition differs from the one used in many statistics relying on Census data (such as the poverty rate) that are based on households that count all adults and children related by blood or marriage who share a residence. For extended families sharing a residence, the SIS definition does not assume shared resources. Our unit of analysis will therefore count fewer resources and may produce higher estimates of financial hardship for these families. Finally, the respondent for the survey is al ways a randomly selected adult in the family unless there are resident children, in which case we select the primary caregiver for those children. Our adult respondents are therefore more likely to be female than those in other data sources.

\section{FIRST-YEAR FINDINGS}

The inaugural report of the $\mathrm{N}$ ew York City Social Indicators Survey provides a first look at the well-being of $\mathrm{N} \mathrm{ew}$ Yorkers using a wide array of measures. Like the Dickens novel, A Tale of Two Cities, we find that for some $\mathrm{N}$ ew Yorkers this is the best of times and for others it is perhaps the worst of times. In a city as full of contrasts as $\mathrm{N} \mathrm{ew}$ York, the story is inevitably even more complex than this. The story of $\mathrm{N}$ ew York City in 1997 is not a tale of two cities, but a tale of many cities.

\section{New York City and the United States}

We find both good news and bad news about two of the most fundamental human assets of $\mathrm{N}$ ew Yorkers: health and education (Table 1). The news about heal th is good. More than three fourths of adults report either good or excellent heal th. Even more encouraging is the finding that more than 90 percent report their children's health to be good to excellent. Comparable data from nationally representative surveys suggest that $\mathrm{N}$ ew Yorkers are about as healthy as A mericans are on the whol $e^{1}$

W ith respect to education, there is less cause for cheer and, in fact, cause for worry. The good news is that the majority of $\mathrm{New}$ York children are at or above the grade level for their age. Although children seem to be doing pretty well in school on average, the fact that as many as 16 percent are falling behind or in special education is cause for concern. Even more worrisome is the fact that school achievement declines steadily with age. W hile 88 percent of $\mathrm{N}$ ew York children under age ten are at grade level, only 79 percent of those between ages fifteen and eighteen are doing as well. The large number of $\mathrm{N}$ ew York children who are falling behind as they approach graduation is consistent with indicators of educational achievement among adults in the city. The proportion of $\mathrm{N}$ ew York adults with college or post-graduate degrees is about the same as the national average of 22 percent. ${ }^{2}$ But almost one-third of the $\mathrm{New}$ York City adults in our survey had only a high school education and about the same proportion had not completed high school- a rate much higher than the national dropout rate of 19 percent. $^{3}$ 
Due to small sample sizes and measurement difficulties, our data on financial assets must be interpreted cautiously. Even the most sophisticated surveys of weal th tend to understate the true value of financial assets, and the simple measures used in this survey are likely to undercount weal th even more. R espondents who refuse to answer sensitive questions about their family finances exacerbate the problem. K eeping in mind these limitations, the SIS begins to paint a portrait of inequality in the city.

\begin{tabular}{|c|c|c|c|c|c|}
\hline Indicator & Response & Percent & Indicator & Response & Percent \\
\hline \multirow[t]{5}{*}{ Adult's health is... } & Excellent & 30 & \multirow[t]{4}{*}{ Family... } & Owns home & 26 \\
\hline & Good & 46 & & Rents home & 67 \\
\hline & Fair & 19 & & Is just "staying there" & 8 \\
\hline & \multirow[t]{2}{*}{ Poor } & 5 & & & \\
\hline & & & \multirow[t]{5}{*}{ Family income relative to poverty line... } & Morethan 10 times poverty & 5 \\
\hline \multirow[t]{4}{*}{ A dult has condition that... } & No limiting condition & 81 & & Between 4 and 10 times & 22 \\
\hline & Limits work & 10 & & Between 2 and 4 times & 24 \\
\hline & \multirow[t]{2}{*}{ Prevents work } & \multirow[t]{2}{*}{9} & & Between 1 and 2 times & 20 \\
\hline & & & & At or below poverty & 29 \\
\hline \multirow[t]{4}{*}{ Adult's highest education is... } & College degree or more & 21 & & & \\
\hline & Some post-high school & 19 & \multirow[t]{3}{*}{ Dueto (lack of) money, utility bills were... } & Always paid on time & 82 \\
\hline & Only high school/GED & 31 & & Sometimes late & 17 \\
\hline & Less than high school & 30 & & Utilities shut off & 1 \\
\hline \multirow[t]{5}{*}{ Child's health is... } & Excellent & 63 & \multirow[t]{3}{*}{ Dueto (lack of) money, family members... } & N ever went hungry & 94 \\
\hline & Good & 30 & & Sometimes went hungry & 7 \\
\hline & Fair & 5 & & & \\
\hline & \multirow[t]{2}{*}{ Poor } & \multirow[t]{2}{*}{1} & \multirow[t]{2}{*}{ Family's housing is... } & $\mathrm{N}$ ot substandard & 84 \\
\hline & & & & Substandard & 16 \\
\hline \multirow[t]{4}{*}{ Child has disability that limits... } & No limiting condition & 94 & & & \\
\hline & Activities a little & 3 & \multirow[t]{3}{*}{ Rooms per person in family housing... } & 2.2 or more & 33 \\
\hline & \multirow[t]{2}{*}{ Activities a lot } & \multirow[t]{2}{*}{3} & & Between 1 and 2.2 & 55 \\
\hline & & & & Less than 1 & 12 \\
\hline \multirow[t]{3}{*}{ Child is... } & At or above grade level & 84 & & & \\
\hline & \multirow[t]{2}{*}{ Below grade level } & \multirow[t]{2}{*}{16} & \multirow[t]{5}{*}{ A dult rates neighborhood as... } & Very good & 29 \\
\hline & & & & Pretty good & 36 \\
\hline \multirow[t]{3}{*}{ Parent reports child has... } & No behavior problems & 42 & & Only fair & 27 \\
\hline & At least one problem & 29 & & Poor & 9 \\
\hline & Two or more problems & 29 & & & \\
\hline \multirow[t]{4}{*}{$\begin{array}{l}\text { Family could borrow from a relative } \\
\text { or friend... }\end{array}$} & At least $\$ 10,000$ & 20 & \multirow[t]{4}{*}{$\begin{array}{l}\text { Walking in neighborhood at night, } \\
\text { adult feels... }\end{array}$} & Very safe & 30 \\
\hline & $\$ 1,000$ but not $\$ 10,000$ & 31 & & Somewhat safe & 43 \\
\hline & $\$ 100$ but not $\$ 1,000$ & 33 & & Somewhat unsafe & 14 \\
\hline & $\mathrm{N}$ ot even $\$ 100$ & 16 & & Very unsafe & 13 \\
\hline \multirow[t]{4}{*}{ Family's total assets are... } & $\$ 100,001$ or more & 16 & \multirow[t]{4}{*}{ In prior year, family members were... } & $\mathrm{N}$ ot crime victims & 89 \\
\hline & $\$ 5,001$ to $\$ 100,000$ & 21 & & Robbed or burglarized & 11 \\
\hline & $\$ 1$ to $\$ 5,000$ & 19 & & & \\
\hline & $\$ 0$ or negative & 44 & & & \\
\hline
\end{tabular}

Source: Garfinkel and M eyers (1999). 
In terms of the good news, it is noteworthy that 16 percent of $\mathrm{N}$ ew York families report a net worth, including home equity and other forms of weal th, of more than $\$ 100,000$. Many N ew York families are clearly doing very well. This good news is tempered, however, by the fact that comparable data for the country as a whole indicate that as many as 30 percent of all families have assets in excess of $\$ 100,000 .{ }^{4}$ The worst news about the financial assets of $\mathrm{N}$ ew Yorkers is the very large proportion of families who have zero or negative net worth. Forty-four percent of families report no assets. Onehalf of these families have no net worth and the other half owe more than they own. This proportion is much higher than the 12 percent of all U.S. families that report zero or negative wealth, ${ }^{5}$ suggesting that on average, $\mathrm{N}$ ew York families lag well behind the rest of the country in their accumulation of assets.

One important factor in the gap between $\mathrm{N} \mathrm{ew}$ York and the rest of the country are the much lower rates of home ownership in the city. Home equity is the most common form of weal th for U.S. families, but nearly three quarters of $\mathrm{N}$ ew Yorkers do not own their homes. This is more than twice the national average of 35 percent. $^{6}$

Access to capital from family and friends is a form of social asset. In small amounts, loans from family or friends may be a critical form of support when families face a financial crisis or need to make a routine transition such as a residential move. In larger amounts, such loans can provide opportunities for starting small businesses and other forms of investment. A bout half of $\mathrm{N}$ ew York families believe they have access to at least a small financial cushion of at least $\$ 1,000 ; 20$ percent have access to $\$ 10,000$ or more. In sharp contrast, as many as 16 percent of families do not believe they could borrow even $\$ 100$ in an emergency.

Given the growth of income inequality, some observers have described $\mathrm{N}$ ew York City as "hollow in the middle." Our indicators of human, financial, and social assets suggest that the city may be better described as "bloated at the bottom" by the large number of families who lack basic education and who have failed to accumulate any financial wealth. Indicators of current economic wellbeing tell a very similar story.
At the top of the income distribution, 5 percent of $\mathrm{N}$ ew Yorkers live in families with incomes greater than ten times the federal poverty level - the same proportion that is observed in the nation as a whole. ${ }^{7}$ But the 29 percent of $\mathrm{N}$ ew York families with incomes that fall below the federal poverty threshold is nearly twice the 15 percent of U.S. families who fall below the threshold when we apply the same definition of family resources to Census Bureau data. In comparison to conventional Census Bureau estimates that count all household income, the $\mathrm{N}$ ew York City Social Indicators Survey measures family income by counting only the resources of nuclear family members (respondent, spouse/partner and dependent children); this calculation overestimates poverty by approximately 4 percentage points. $\mathrm{N}$ evertheless, the evidence that $\mathrm{N}$ ew York City is bloated at the bottom is unambiguous.

Rates of income poverty correspond closely to compromises in living conditions. The rate of incomerelated hunger is twice as high in the city as it is in the nation. ${ }^{8} \mathrm{G}$ iven its scarcity, it is not surprising that housing inadequacies are even more acute than hunger in the city. $\mathrm{H}$ ousing problems are al so considerably more common in $\mathrm{N}$ ew York City than in the nation as a whole. The good news is that the large majority of $\mathrm{N}$ ew York familieslive in housing that is not considered substandard or overcrowded. But 16 percent of $\mathrm{N}$ ew York City families do live in housing with major structural problems or utility breakdowns. ${ }^{9}$ Twelve percent of families al so live in dwellings that have less than one room per household member. This is four times the national average. ${ }^{10}$

Physical security is one of the distinguishing features of a civil society and a powerful indicator of the quality of life. That crime rates have dropped substantially in $\mathrm{N}$ ew York City in recent years is certainly good news. ${ }^{11}$ The SIS reveals that 11 percent of $\mathrm{N}$ ew York City families were victims of a robbery or burglary in the prior year, only slightly higher than the national average of 9 percent. ${ }^{12}$ W hether that is good or bad news is unclear. By international standards, the U nited States continues to have very high crime rates. H owever, 30 percent of adults interviewed for the survey report that they feel very safe walking in their neighborhood at night and 
another 43 percent consider themselves at least somewhat safe. This is encouraging news about the city. And it provides further evidence that the experience of crime for $\mathrm{N} \mathrm{ew}$ Yorkers may not be dramatically different from that for Americans more generally: In response to a similar question in a 1997 Gallup poll, 61 percent of U.S. residents indicated that they were not afraid to walk near their homes at night. 13

The well-being of $\mathrm{N}$ ew Yorkers depends not only on their economic resources but also on the security and quality of a variety of external supports. Some of these supports - such as health insurance - are provided by both government and market institutions. Others- such as schools- are provided through an even more diverse combination of public, community, and religious institutions. W hile $\mathrm{N}$ ew Yorkers describe themselves as generally satisfied with many of these institutions, there appear to be serious problems of access and qual ity in some areas.

$\mathrm{H}$ ealth insurance coverage is one of the most important external supports for families and, for $\mathrm{N} \mathrm{ew}$ Yorkers, one of the most problematic. Slightly more than two-thirds of $\mathrm{N}$ ew York families were fully insured for the whole year through either private health plans or government programs such as M edicaid and M edicare. In nearly one-quarter of families, some or all of the family members lacked insurance when contacted. In another 9 percent, at least one family member had gone without insurance at some point in the prior year. These figures are considerably higher than the 14 to 15 percent of U.S. residents who are uninsured at a point in time, and the additional 6 to 7 percent of adults who lack insurance for at least one month out of the year. ${ }^{14}$

H owever, the problem of obtaining health insurance appears to be much more acute for $\mathrm{N}$ ew Yorkers than the quality of the coverage they obtain. A mong those who have some kind of heal th insurance coverage, about half describe themselves as very satisfied with their plan and another third are at least somewhat satisfied. $\mathrm{N}$ ew York parents are even more positive about the school their child attends. A bout two-thirds of parents agree that their child's school is safe and provides a good education; another one-quarter somewhat agree.

\section{The POOR AN D N ON POOR: In Equality OF IN COME AND OF OUTCOMES}

Taking the "average" temperature of $\mathrm{N}$ ew York tells us that the city is different from the rest of the country. On average, its residents are poorer in income and assets, less well educated, less likely to be homeowners, more likely to be living in overcrowded housing, less likely to have heal th insurance, and less positive, overall, about their neighborhoods. But N ew York is not a city of averages; it is a city of diversity and extremes. The myth of America as a melting pot has been pervasive. The $\mathrm{N}$ ew York City Social Indicators Survey documents a different reality: In terms of assets, living conditions, and experience with the city's institutions, the diverse groups of $\mathrm{N}$ ew York City do not melt together, but remain far apart.

Some of the starkest differences are reveal ed when we compare $\mathrm{N}$ ew Yorkers who differ by income. Over onequarter of all $\mathrm{N}$ ew York families have incomes at or below the federal poverty threshold and another one-fifth are nearpoor, with incomes between one and two times the poverty threshold. Slightly more than onequarter of families, in contrast, might be considered "affluent," or at least economically secure, with incomes at least four times the poverty threshold. Inequal ity between these families is great, not only in income, but in measures of well-being ranging from living conditions to the accumulation of assets.

In terms of human assets, the poor and near-poor of $\mathrm{N}$ ew York are struggling indeed (Table 2). The respondent in one-third or more of these families reports fair to poor health; one-quarter also report a work-limiting disability. The gap between rich and poor is vast: The odds that a poor adult is in poor health are more than eight times those of an affluent adult; his or her odds of being disabled are more than ten times greater. Educational disadvantage is also highly concentrated. In half of poor and near-poor families, one or both adults lack the equival ent of a high school education.

It is difficult to sort out the causal sequence linking adults' human assets and poverty. Poor health and education may be a consequence of income poverty and restricted opportunity; they are al so an important contributing factor to low earnings and poverty. In the case of 
SOCIAL IN DICATORS BY In COME RELATIVE TO POVERTY

\begin{tabular}{|c|c|c|c|c|c|}
\hline Indicator & Percentage Poor & Percentage N ear-Poor & Percentage M iddle Class & Percentage A ffluent & Odds Ratio: Poor versus Affluent \\
\hline R espondent in fair to poor health & 35 & 43 & 11 & 6 & 8.0 \\
\hline Respondent disabled & 28 & 22 & 10 & 4 & 10.2 \\
\hline A ny adults without high school & 51 & 51 & 13 & 6 & 15.4 \\
\hline Child in fair to poor health ${ }^{a}$ & 8 & 8 & 5 & 5 & 1.6 \\
\hline Child disabled ${ }^{a}$ & 13 & 9 & 6 & 6 & 2.3 \\
\hline Child not at or above grade level & 33 & 10 & 7 & 7 & 6.6 \\
\hline Could not borrow $\$ 100$ & 33 & 11 & 8 & 4 & 10.9 \\
\hline H unger in prior year & 11 & 4 & N.A. & N.A. & N.A. \\
\hline Late utility payments in prior year & 25 & 24 & N.A. & N.A. & N.A. \\
\hline Overcrowded housing & 23 & 12 & 6 & 4 & 6.5 \\
\hline Substandard housing & 27 & 14 & N.A. & N.A. & N.A. \\
\hline Feel unsafe in neighborhood & 36 & 40 & 21 & 13 & 3.8 \\
\hline R ate neighborhood fair to poor & 49 & 38 & 31 & 16 & 5.1 \\
\hline A dult(s) lacks health insurance & 26 & 23 & 19 & 18 & 1.6 \\
\hline Child(ren) lacks health insurance & 20 & 30 & 11 & 6 & 4.0 \\
\hline Parent rates child's school as poor & 22 & 24 & 16 & 12 & 2.1 \\
\hline Preschool child not in formal care & 81 & 53 & 57 & 51 & 4.3 \\
\hline \multicolumn{6}{|l|}{ Memo: } \\
\hline Unweighted number & 287 & 220 & 406 & 435 & \\
\hline Percentage weighted & 30 & 20 & 24 & 27 & \\
\hline
\end{tabular}

Source: Garfinkel and Meyers (1999).

N ote: U nless otherwise noted, group differences are statistically significant at the 95 percent confidence level.

${ }^{a} \mathrm{G}$ roup differences are not statistically significant at the 95 percent confidence level.

children, however, the significance of compromises in human assets is much more straightforward. It cannot be argued that children's poor health or education cause their income poverty. Compromises in children's human assets are much more clearly a consequence of poverty and, perhaps more importantly, a predictor of economic difficulties in the future.

On the whole, children in poor $\mathrm{N}$ ew York families are much healthier than adults. Children are also much less likely to be disabled than adults. It is good news that as many as 85 to 90 percent of poor children are in good health and free from activity-limiting problems. This suggests that children in poor families may not have paid as great a price as adults in terms of their health status. Whether this bodes equally well for the future depends on how well these children fare as they age. Here the news is not so reassuring.
The prevalence of childhood physical health, mental health, and learning problems generally increases with age. The jump is particularly sharp during the school years, when children are identified for special services within the school system. $N$ ational data show, for example, that 2 percent of children under age three have identified disabilities, and the proportion rises steadily with age until it reaches 6 percent of school-age children and 9 percent of adolescents (Aron, Loprest, and Steuerle 1996). A similar pattern is evident in the $\mathrm{N}$ ew York data (Table 3). A mong all children, the proportion with some form of health problem or disability increases substantially from early childhood to adolescence. This increase would be expected, as health and learning problems are manifested and diagnosed throughout childhood. 
W hat should not be expected is that as the preva lence of childhood difficulties grows, so too does the gap between the advantaged and disadvantaged. Translated into the language of odds, among children under age six, the odds that a poor child is disabled or in bad health are about the same as those of an affluent child; among older children, the odds of disability and health problems are nearly two to three times greater among poor children.

Poor children's school performance and behavioral adjustment are al so far behind those of their more affluent peers (Table 2). On the whole, children in N ew York are doing pretty well. Problems are highly concentrated, however, among children in the poorest families. In comparison to affluent children, the odds that a poor child is behind at least one grade are more than six times greater; the odds that he or she has adjustment problems are two times greater. Like health, school and behavior problems are worse among older children, and the difference between advantaged and disadvantaged children is wider. By age seventeen, the odds of being behind a grade are more than six times greater for poor children than for affluent children, and the odds of having behavior problems are more than three times greater.

These data show that poor adults and children in $\mathrm{N}$ ew York are lagging far behind their richer counterparts in terms of human assets. We should not be surprised to

\begin{tabular}{|c|c|c|c|}
\hline \multicolumn{4}{|c|}{$\begin{array}{l}\text { Table } 3 \\
\text { CHILD OUtCOMES By POVERTY By AgE }\end{array}$} \\
\hline Outcome & $\begin{array}{l}\text { Percentage } \\
\text { Poor }\end{array}$ & $\begin{array}{l}\text { Percentage } \\
\text { Affluent }\end{array}$ & $\begin{array}{c}\text { Odds R atio: } \\
\text { Poor versus Affluent }\end{array}$ \\
\hline \multicolumn{4}{|l|}{ Child disabled } \\
\hline Age zero to five & 3 & 3 & 1.0 \\
\hline Age six to seventeen & 20 & 9 & 2.6 \\
\hline \multicolumn{4}{|c|}{ Child in fair to poor health } \\
\hline Age zero to five & 5 & 5 & 1.0 \\
\hline Age six to fourteen & 10 & 5 & 1.7 \\
\hline \multicolumn{4}{|l|}{ M emo: } \\
\hline Unweighted number & 287 & 435 & \\
\hline Percentage weighted & 30 & 27 & \\
\hline
\end{tabular}

Source: Garfinkel and M eyers (1999).

$\mathrm{N}$ ote: Group differences are statistically significant at the 95 percent confidence level. find that poor families are al so far behind in the accumulation of any financial assets. Over two-thirds of poor $\mathrm{New}$ York families report zero or negative assets. Families at the bottom of the economic ladder are al so poor in terms of access to resources that might help them weather a financial crisis or routine transition, such as a move or the start of a new job. One-third of the poorest families do not have access to even $\$ 100$ in emergency funds. This is a sobering reminder of how disadvantage accumulates: Poor families are disadvantaged not only in their own resources but also in their ability to get, or give, financial help to kith and kin.

Financial insufficiency translates into a number of compromises in the economic and living conditions of the poorest $\mathrm{N}$ ew Yorkers. Food insufficiency is highly concentrated among the poor, affecting 11 percent of families. One-quarter of the poor have faced difficulty with utility payments. About one in four poor $\mathrm{N}$ ew York families is also living in overcrowded housing and 27 percent live in housing that had serious structural, plumbing, or heating problems.

Income is less predictive of crime victimization. The SIS suggests that the much-heralded drop in the crime rate has benefited most $\mathrm{N}$ ew Yorkers. W hile the poor are somewhat more likely than the rich to have been crime victims in the prior year, their overall odds of victimization are not much greater than those of other families. Differences are evident, however, in the type of victimization. Poor families are only about half as likely as rich families to have been subject to property crime in the form of having their homes broken into. Their odds of having been the victim of a robbery, in contrast, are four times greater. Given these differences, it is not surprising that one-third of the poorest $\mathrm{N}$ ew Yorkers feel that their neighborhoods are unsafe and one-half rate their neighborhoods negatively.

We would hope that public services and supports would offset these incomerelated forms of inequality. The evidence for this, however, is not reassuring. In fact, the poorest families are often the most disadvantaged in the adequacy of institutional supports as well.

This is most notable in children's health insurance. Children in 20 percent of the poorest families lack health 
insurance; their odds of going uninsured are four times greater than those in the most affluent families. It is not the poorest families, however, but the near-poor families who fare the worst in this dimension, with a full 30 percent unable to insure their children. The problem remains most acute for these families at the margin of self-sufficiency, who often fall between the cracks of public programs and empl oyment-based insurance. Poorer families al so do much worse than their affluent counterparts in terms of educa tional resources for their children. Parents in 22 percent of the poorest families rate their children's school as unsafe and/or providing poor education, in comparison with only 12 percent of parents in the most affluent families; children in more than 80 percent of the poorest families are not in formal child care, in contrast to 50 percent of their counterparts in affluent families.

\section{CONCLUSIONS}

Taken together, these findings help explain why $\mathrm{New}$ York, on "average," is so different from the rest of the country. The United States has more economic inequality than virtually all other W estern industrial ized nations; and among U.S. cities, N ew York City appears to be the most unequal. Great inequality is not a new phenomenon for the country or the city. The dramatic pulling apart of rich and poor is new, however. In the last twenty years, as the rich have gotten richer, economic and social policy changes have left the poor further and further behind. N ew York stands out among U.S. cities as being the most unequal and as experiencing the greatest rise in inequality during this period (Larin and M CN ichol 1997).

W hether this inequality matters- whether it is or should be a shared concern for all N ew Yorkers- depends in part on its concrete manifestations. It is not a surprise that the poorest $\mathrm{N}$ ew Yorkers are worse off in their economic and social living conditions. It may not be surprising that the poorest $\mathrm{N}$ ew Yorkers are al so worse off in terms of their health and educational attainment. Evidence of inequality in socially controlled external supports and services-from schools and health insurance to police protection- is more surprising and less defensible. Even if we are no longer surprised by the existence of inequality and hardship, the concrete manifestations and the magnitude of the difference between rich and poor $\mathrm{N}$ ew Yorkers remain shocking.

\section{LOOKING AHEAD}

A major contribution of the $\mathrm{N}$ ew York City Social Indicators Survey is to provide a rich description of the well-being of $\mathrm{N}$ ew Yorkers and of the magnitude of income and concrete inequality in the city. W ith each cross-sectional sample, we will use the data to compare well-being across groups that differ by demographic characteristics, family structure, income, and other features. Over time, we will be able to track whether well-being is converging or diverging for these groups - that is, whether inequality is increasing or declining. Because the survey includes a variety of measures of individual- and family-level well-being, ranging from the economic to the interpersonal and social, we will be able to track inequality on multiple dimensions simultaneously and to analyze the accumulation of advantage - and disadvantage — at the individual level.

Our ambitions go beyond description, in that we hope to link changes in well-being and inequality to changes in public policies. One key to this analysis is the collection of data from a large representative sample of households within a single "policy jurisdiction." The household level data in the SIS will be supplemented by detailed information on changes in social policies and programs in N ew York City and N ew York State.

Isolating the effects of policy change from other factors that are likely to influence well-being and inequal itysuch as changes in the local economy and job marketwill present the greatest methodological challenge. We will capitalize on several features of the SIS design to strengthen our ability to make causal interpretations. The collection of data from repeated cross-sections of the entire population will allow us to compare the situations of individuals and families with those of similar respondents in a different policy context. For example, to isolate the effects of changing welfare eligibility rules and administration, we will use the population sample to identify families who are 
eligible for welfare in 1999 and families who are ineligible in 1999 but who would have been eligible under the 1996 rules. Differences in the economic strategies and wellbeing of these two groups will provide insight into the effect of eligibility rule changes.

The challenges of measuring well-being and inequality are vast. The opportunities to contribute to our understanding of these issues are al so great. The SI S project represents one effort to push beyond the limitations of current data sources in order to collect the data necessary to answer questions not only about whether America is becoming more or less unequal, but about what inequality means in concrete terms and how government policies affect its magnitude and consequences. 


\section{EN DN OTES}

1. Authors' calculation, based on theU.S. Bureau of the Census, Current Population Survey, 1996-97.

2. Authors' calculation, based on the U.S. Bureau of the Census, Current Population Survey, 1996-97.

3. Authors' calculation, based on the U.S. Bureau of the Census, Current Population Survey, 1996-97.

4. Authors' calculations, based on the U.S. Census Bureau's Current Population Survey (CPS), A sset Ownership of H ousehold Report, 1993. $M$ easures of assets in the CPS are more extensive than those in the $\mathrm{N}$ ew Y ork City Social Indicators Survey, so the magnitude of the difference between the United States and $\mathrm{N}$ ew $\mathrm{Y}$ ork City may be exaggerated in these comparisons. The low levels of home ownership in N ew Y ork City are consistent with the conclusion that a small proportion of $\mathrm{N}$ ew $\mathrm{Y}$ ork families has assets above $\$ 100,000$.

5. Authors' calculations, based on the U.S. Census Bureau's Current Population Survey, Asset Ownership of H ousehold Report, 1993.

\section{A merican H ousing Survey, 1995 (T able 2-1).}

7. Authors' calculation, based on the U.S. Bureau of the Census, Current Population Survey, 1996-97.

8. U.S. Department of Agriculture $N$ ationwide Food Consumption Survey (N FCS): D ecennial Survey, 1977-80; Supplemental Low-Income Survey, 1987-88; U.S. Department of Agriculture Continuing Survey of Food Intakes by Individuals (CSFII), 1985-86, 1989-91. For U.S. households, food insufficiency (measured as family members going hungry) remained steady, at 2 to 4 percent, between 1977 and 1991.
9. American Housing Survey, 1995. Nationwide, 7.5 percent of occupied homes have structural problems (holes in floor, open cracks in the interior, exposed wiring); 5.0 percent have inadequate heating; 1.5 percent lack some or all plumbing facilities.

10. A merican H ousing Survey, 1995 (Table 2-3). This survey uses more than one person per room as a measure of overcrowding; the $\mathrm{N}$ ew $\mathrm{Y}$ ork City Social Indicators Survey measure is based on rooms per person.

11. N ew Y ork State Division of Criminal J ustice Services, Criminal J ustice Indicators by $\mathrm{Percent} C$ Change: N en Y ork City, 1995-96. N ew Y ork experienced a 3 percent drop overall in reported crime, a 17 percent drop in burglaries, and a 16 percent drop in robberies during this period.

12. Authors' calculations, based on the 1994 General Social Survey (GSS). The GSS asked if the respondent was the victim of burglary or robbery; the N ew Y ork City Social Indicators Survey asks whether the family was victimized. This may inflate our figure relative to thenational data.

13. TheG allup P oll M onthly, Princeton, N . ..: no. 318, pp. 51-2; no. 339 , p. $20 ;$ no. 371, p. 37.

14. Current Population Reports; $D$ ynamics of $E$ conomicW ell-B eing: $H$ ealth Insurance, 1993-95. W ho L oses Coverage and for $\mathrm{H}$ ow L ong? According to 1994 Survey of Income and Program Participation data, 21 percent of adults lacked insurance for at least one month and 8 percent had no insurance for the twelvemonth period. 


\section{REFERENCES}

A ndrews, F. M . 1989. "The Evolution of a Movement." J OURnaL OF Public Policy 9, no. 4: 401-5.

A ron, L., P. Loprest, and E. C. Steuerle 1996. SeRving CHILDREN WITH DISABILITIES. W ashington, D.C.: The Urban Institute Press.

B rown, B , and T. C orbett. 1997. "Social Indicators and Public Policy in the Age of D evolution." U niversity of W isconsin-M adison, Institute for Research on Poverty Special Report no. 72.

B ulmer, M . 1989. "Problems of Theory and M easurement." J OURn AL OF PUBLIC Policy 9, no. 4: 407-12.

Carley, M. 1981. Social Measurement and Social Indicators: ISSUES OF POLICY AN D THEORY. London: George Allen and Unwin.

Citro, F., and R. Michad, eds. 1995. Measuring Poverty: A NeW APPROACH. W ashington, D.C.: N ational A cademy Press.

Cutler, D., and L. Katz. 1992. "Rising Inequality: Changes in the Distribution of Income and Consumption in the 1980s." AMERICAN ECON OMIC REVIEW (M ay): 546-51.

Duncan, G., and J. Brooks-G unn, eds. 1997. CON SEQUeN CES OF GROW IN G UP POOR. N ew Y ork: Russell Sage Foundation.

Edin, K., and L. Lein. 1997. Making Ends MeEt. N ew Y ork: Russell Sage Foundation.

F ederman, M ., T . G arner, K. Short, et al. 1996. "W hat D oes It M ean to Be Poor in America?" M ONTHLY LABOR REVIEW 119, no. 5 (May): 3-17.

G arfinke, Irwin, and M arcia K. Meyers. 1999. A TALe OF MANY Cities: N EW Y ORK CITY SOCIAL IN DICATORS 1997. N eW York: Columbia University School of Social W ork.

J encks, C., and S. M ayer. 1996. "Do Official Poverty Rates Provide U seful Information about Trends in Children's Economic Welfare?" $N$ orthwestern University, Center for Urban Affairs and Poverty Research W orking Paper no. 94-14.

J ohnston, D . F . 1989. "Some R eflections on the U nited States." J OURN AL of PUBLIC Policy 9, no. 4.

J orgenson, D . 1998. "Did W e Lose the W ar on Poverty?" J OURnAL OF ECON OMIC PERSPECTIVES 12, no. 1: 79-96.
Koshd, J. 1997. "Indicators as Tools for Managing and Evaluating Programs at the $\mathrm{N}$ ational, State, and Local Levels of Government." U niversity of W isconsin-M adison, Institute for R esearch on Poverty Special Report no. 73.

Larin, K., and E. M cN ichol. 1997. Pulling Apart: A State-By-State ANALY SIS OF IN COME TREN DS. W ashington, D.C.: Center on Budget and Policy Priorities.

M ayer, S. 1997. "Trends in the Economic W ell-Being and Life Chances of America's Children." In G. Duncan and J. Brooks-Gunn, eds., CONSEQUen Ces OF Growing UP POOR. N ew York: Russell Sage Foundation.

M ayer, S., and C. J encks. 1988. "Poverty and the Distribution of Material H ardship." J OURN AL OF HUMAN RESOURCES 24: 88-113.

- - - . 1995. "H as Poverty Really Increased among Children since 1970?" N orthwestern University, Center for Urban Affairs and Poverty R esearch W orking Paper no. 94-14.

Passero, W . 1996. "Spending Behavior of Families Receiving W elfare or Public Assistance." Paper presented at the Forty-Second Annual Conference of the American Council on Consumer Interests, N ashville, Tenn., March 27-30.

Rector, R . 1992. "H ow the Poor Really Live: Lessons for W elfare R eform." The H eritage Foundation Backgrounder no. 875, January 31.

Ruggles, P. 1990. Drawing the Line-Alternative Poverty MeAsures and TheIR Implications for PUbliC POLICY. W ashington, D.C.: The U rban Institute Press.

Sherman, A . 1994. The Children's Defense Fund Report on the COSTS OF CHILD POVERTY. Boston: Beacon Press.

Slesnick, D. 1993. "Gaining Ground: Poverty in the Postwar United States." J OURn AL OF POLITICAL ECON OMY 101, no.1 (February): 1-38.

Smeding, T., and P. G ottschalk. Forthcoming. "Empirical Evidence on Incomel nequal ity in Industrialized Countries." I n A. B. Atkinson and F. Bourguignon, eds., HANDBOOK OF INCOME DISTRIBUTION. A msterdam: Elsevier/N orth-H olland.

U.S. D epartment of $\mathrm{H}$ ealth and H uman Services. Office of the A ssistant Secretary for Planning. 1998. TRENDS IN THE W ELL-BEING OF AMERICA'S CHILDREN AND YOUTH. W ashington, D.C.: U.S. $D$ epartment of $\mathrm{H}$ eal th and $\mathrm{H}$ uman Services. 